\title{
Postoperative topical analgesia of hemorrhoidectomy with policresulen and cinchocaine: a prospective and controlled study
}

\section{Analgesia tópica com policresuleno e cinchocaína no pós-operatório de hemorroidectomias: um estudo prospectivo e controlado}

Ilario Froehner Junior, AsCBC-SC'; Paulo Gustavo Kotze"; Juliana Gonçalves Rocha'; Eron Fábio Miranda ; Maria Cristina

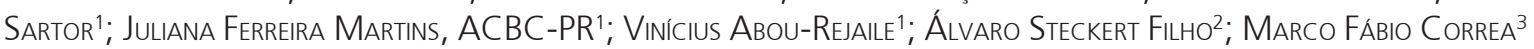

\section{A}

\begin{abstract}
Objective: To evaluate the effects of topical policresulen and cinchocaine in the postoperative pain behavior of open hemorrhoidectomy. Methods: We conducted a prospective, double-blinded, controlled study. The control group received the usual guidelines with oral medications. The topical treatment group received, in addition, the application of the ointment and was comprised of two subgroups (policresulen + cinchocaine, and placebo). Pain intensity was recorded with the visual analogue scale. Results: 43 patients were operated on: control group $-n=13$, one excluded; placebo $-n=15$; and policresulen + cinchocaine $\mathrm{n}=15$. The mean age was 45.98 years and $37.2 \%$ were men. The average pain intensity was 4.09 (immediate postoperative), 3.22 (hospital discharge), 5.73 (day 1) , 5.77 (day 2), 5.74 (day 3), 5.65 (day 7), 5.11 (day 10), 2.75 (day 15) and 7.70 (first bowel movement), with no difference between groups in all periods. Conclusion: This study showed no reduction in pain after hemorrhoidectomy with the use of topical policresulen and cinchocaine.
\end{abstract}

Key words: Hemorrhoids. Hemorrhoidectomy. Pain, postoperative. Analgesia.

\section{INTRODUCTION}

$\mathrm{T}$ he clinical topical treatment for hemorrhoids using ointments, creams and suppositories is widespread and routinely used by most proctologists ${ }^{1}$. It is a conduct with no supporting scientific data ${ }^{2}$.

A recent meta-analysis on the surgical treatment of hemorrhoids considered pain as a major complication of hemorrhoidectomy ${ }^{3}$. According to Ho et al., many patients prefer to live with the prior hemorrhoidal symptoms than endure postoperative pain. Attempts to minimize it divide proctologists between pre and postoperative ones, with no consensus or consolidated guidelines in this regard ${ }^{4}$.

The usual hemorrhoidectomy postoperative period is composed of hygienic-dietary guidelines, oral analgesics and medications aimed at the formation of pasty feces, facilitating elimination ${ }^{5}$.

The combination of topical policresulen and cinchocaine, without addition of corticosteroids and antibiotics, has wide acceptance by patients and indication by physicians for the clinical treatment of hemorrhoids, and quite controversially, in postoperative management. According to Spinoza, the compounds containing policresulen and cinchocaine for prolonged treatment of internal and external hemorrhoids are responsible for therapeutic success in over $80 \%$ of patients ${ }^{6}$.

Policresulen, the main component of the association, is an organic acid of high molecular weight, of ionic potential hydrogen $(\mathrm{pH})$ equal to 4 , whose half-life ranges from four to five hours. It has hemostatic activity by causing coagulation of blood proteins and promoting the contraction of the muscular fibers of the blood vessels of small caliber. It ptomotes selective chemical debridement: being an anion, it has the ability to interact only with the phospholipid molecules of the plasma membranes of to devitalized cells, which have lost its original electric charge. This contact provides the denaturation of cellular proteins, facilitating their removal. Its acidity, together with coagulating properties, give policresulen antimicrobial activity against staphylococcus spp., streptococcus spp. and Candida albicans ${ }^{7}$. The debridement and antimicrobial action of policresulen make it an important agent in the process of healing. The cinchocaine (dibucaine) is a topical anesthetic of the amide group, the same as lidocaine, mepivacaine, prilocaine and bupivacaine, differing by the presence of a double aromatic ring in its lipophilic moiety. It features fast action, in approximately 15 minutes, with peak activity lasting between two and four hours ${ }^{8}$.

1. Coloproctology Service of the University Hospital Cajuru, Pontifícia Universidade Católica do Paraná - (PUCPR); 2. University Hospital, Universidade Federal de Santa Catarina (UFSC); 3. Post-Graduation Program in Zoology, Universidade Federal do Paraná (UFPR). 
Similarly to what happens in the clinical management of hemorrhoids, postoperative topical treatment is controversial, having no consistent results in the literature 1. According to Cruz et al., postoperative care divide proctologists who are dedicated to operate on patients with hemorrhoidal disease, with constant endless discussions about the approaches adopted by each ${ }^{9}$. There is no published consensus on this topic.

Given this scenario of uncertainty, the objective of this study was to evaluate the effects of topical policresulen and cinchocaine on intensity of pain in the postoperative period of patients undergoing hemorrhoidectomy compared with use of placebo and non use of ointments.

\section{METHODS}

This study was approved by the Ethics in Research Committee of the Center for Bioethics at the Pontifical Catholic University of Paraná (PUCPR), number 5297/11.

This study was a prospective, longitudinal, doubleblind, placebo-controlled trial. From May to September 2011 we evaluated patients from the General Proctology Clinic of the Cajuru University Hospital undergoing hemorrhoidectomy.

Patients were divided into two groups: control and topical treatment. The first consisted of patients who received routine post-operative orientations without the use of topical treatment with ointments, only oral medications, and general guidelines. The topical treatment group was composed of patients who, in addition to routine guidelines, received prescription of ointment for application to the wound three times a day for seven days. This group was randomly divided into patients who used policresulen and cinchocaine and others who used neutral ointment (placebo), composed of $30 \%$ petroleum jelly, lanolin $30 \%$, $3 \%$ EDTA and propylene glycol qs. Both patients and researchers were blinded to this treatment/placebo assigment. The study design is illustrated in Figure 1.

Patients included were of both sexes, 18-70 years, with symptomatic grade III and IV ${ }^{10}$ mixed hemorrhoidal disease refractory to medical treatment. All were operated on by the same surgeon and had their three hemorrhoids resected by the Milligan-Morgan technique ${ }^{11}$. Moreover, they fit the anesthetic criteria for submission to outpatient surgical procedure according to the guidelines of the American Society of Anesthesiologists 5 .

We excluded patients who had undergone any anorectal operation, patients with mental disorders, patients allergic to dipyrone and NSAIDs, patients who refused to complete the questionnaire or who had not completed the questions posed in the return to the clinic. Moreover, we also excluded those who did not follow the general postoperative guidelines or had not used the ointment, as well as pregnant patients, due to the inconsistency of data on the toxicity of policresulen and cinchocaine in this group ${ }^{6}$.

All patients were treated at the day hospital sector of the Cajuru University Hospital. The operations were performed by the open technique (Milligan-Morgan) ${ }^{11}$ under combined anesthesia (induced with intravenous propofol + local) 5. Patients also received dipyrone $1 \mathrm{~g}$ and $100 \mathrm{mg}$ intravenous ketoprofen, administered by the anesthesiologist during the procedure.

All patients received the same prescriptions containing analgesics administered in the ward. We administered $1 \mathrm{~g}$ dipyrone intravenously every six hours, $50 \mathrm{mg}$ tramadol hydrochloride intravenously every eight hours and 50mg tramadol hydrochloride intravenously, if necessary.

To discharge, patients were evaluated by the principal investigator, between six and eight hours after the procedure, aimed at satisfying the conditions of hospital release after ${ }^{12}$. The supplied postoperative instructions, equal for both groups, purported to eating behaviors, bowel movements, hygiene maneuvers, sitz baths, and risk signs and symptoms that would demand hospital return for reassessment.

Oral analgesia to both groups included $1 \mathrm{~g}$ dipyrone every six hours for ten days, $10 \mathrm{mg}$ ketorolac tromethamine every eight hours for seven days and $50 \mathrm{mg}$ tramadol hydrochloride, for persistent pain, besides the two medicines listed above. Lactulose $667 \mathrm{mg} / \mathrm{mL}$ was taken twice daily, $10 \mathrm{~mL}$ each time for seven days.

The topical treatment group additionally received a prescription ointment, a tube of $30 \mathrm{~g}$, with the guidance of topical application in the surgical wounds three times daily for seven days (they were instructed to put about one $\mathrm{ml}$ of ointment on the index finger and apply it smoothly on the operated region). Each patient received only one

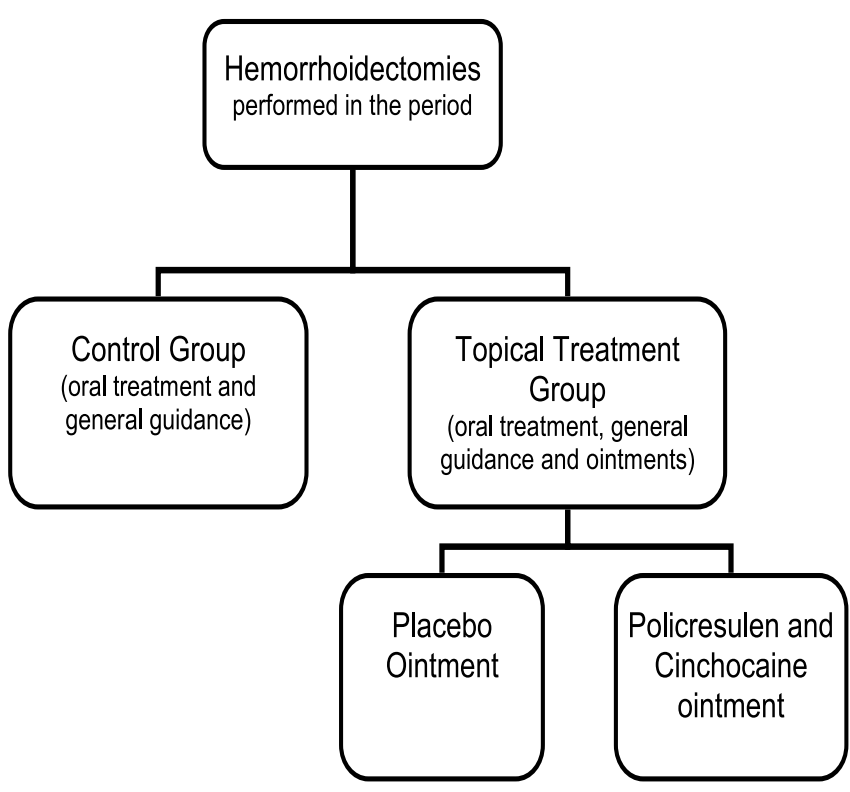

Figure 1 - Schematic drawing of the study with groups of patients. 
unit of product. Ointments were made in a manipulation pharmacy, according to the norms of production and packaging of the product. The tubes of ointment, identical to each other, were numbered and identified by the provider, who recorded the composition in a sealed document, open only in the end of the study by the principal investigator.

The distribution of patients in the study groups was made randomly. There was no known systematization of the randomization.

Through the Visual Analog Scale (VAS - Figure $2)^{13}$, received with postoperative guidelines, the patient was instructed to associate the sensation of pain to a number from 0 to 10 (no pain to extreme pain, respectively). The records were made at the time the patient arrived at the ward, at hospital discharge, after the first evacuation and after one, two, three, seven, ten and 15 days postoperatively. Additionally, we asked the patient to respond affirmatively or negatively on the performance of postoperative instructions. In the topical treatment group, there was still the question about the use of the ointment on the degree of patient satisfaction.

Statistical analysis of demographic data was performed by applying the chi-square and Kruskal-Wallis tests. The assessment variables related to the measurement of pain was performed using the Kruskal-Wallis test. The nominal qualitative variables were assessed by the Fisher's exact test. The significance level used in all statistical tests was 0.05 . The primary study hypothesis was that there would be no difference between the control, placebo and ointment groups in the analysis of postoperative pain using a visual analog scale (VAS).

\section{RESULTS}

Forty-three patients underwent hemorrhoidectomy. Of these, 13 comprised the control group. A male patient of this group was excluded for not properly completing the questionnaire for assessing pain. Of the remaining 30 patients comprising the topical treatment group, 15 were included in the placebo group and fifteen in the use of policresulen and cinchocaine ointment group (Figure 3).

The mean age of all patients was 45.98 years. In the control group, the mean was 42.84 , in the placebo, 50.26 , and in ointment group the mean age was 44.86 years. There was no statistical age difference between the analyzed groups (Kruskal-Wallis, $p=0.27$ ). Of all patients included, $37.2 \%$ were men and $62.8 \%$ women. In the control group, the distribution was $66.66 \%$ and $33.33 \%$. In the placebo group, $26.66 \%$ and $73.33 \%$ and in policresulen + cinchocaine group, $20 \%$ and $80 \%$, respectively. The chi-square test revealed no statistical difference for gender in the control and placebo groups ( $p$ $=0.16$ and $p=0.07)$, though present in the policresulen + cinchocaine group $(p=0.02$ ) (Table 1$)$.

The mean pain intensity assigned by patients upon arrival to the ward was 4.09 (control group - 3.41; the placebo group - 3.93; and policresulen + cinchocaine group - 4.93), with no statistical difference between groups ( $p=$ 0.40). At hospital discharge, the mean values of the painful sensation measured by the visual analog scale was 3.22 (control group - 2.75; placebo - 2.8; and policresulen + cinchocaine - 4.13), also with no statistical difference between groups $(p=0.36)$.

At the end of the first postoperative day, the mean pain noted by patients was 5.73 in the overall analysis, with no statistical significance $(p=0.67)$. On the second day after surgery the average rate was 5.77 in all patients, again with no statistical difference between groups ( $p=$ 0.3 ). At the end of the third postoperative day, mean pain was 5.74 among all patients, without statistical significance $(p=0.22)$.

On the seventh day after surgery, the mean of the values assigned to pain was 5.65 in the total population sample, without statistical difference between groups ( $p=$ 0.45). On the tenth day, the average was 5.11 in total, also with no statistical difference $(p=0.69)$. On the 15th day (outpatient visit), the mean values of pain reported by patients was 2.75, with no significant difference between groups $(p=0.41)$.

According to the analysis with the Kruskal-Wallis,

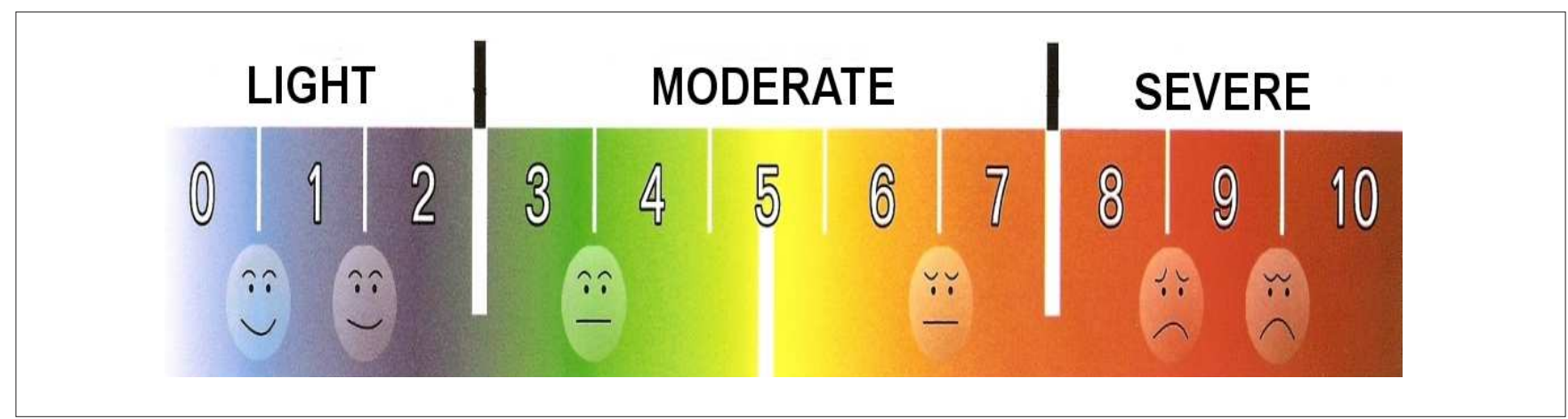

Figure 2 Visual Analogue Scale (VAS), from 0 to 10 , used to measure patients' pain ${ }^{13}$ 
Table 1 - Demographic data.

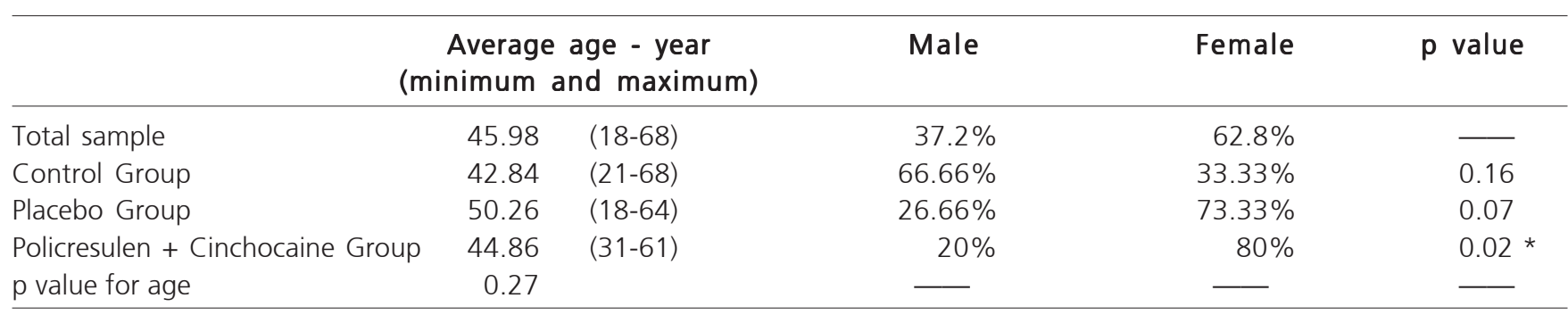

* The gender distribution in the policresulen + cinchocaine group showed statistical significance (chi-square test)

there was no statistical differences in pain intensity in patients from the three groups at all postoperative periods included in the analysis. The curves drawn in accordance with the values reported have the same graphic pattern, with a plateau of greater pain intensity between the first and tenth days after surgery (Figure 4).

The first evacuation occurred, on average, between the second and third days after surgery, ranging from the first to the seventh day. In the control group the average was 2.5 days (range $1-4, S D=1$ ) in the placebo group, 2.43 (range $1-7, S D=1.55$ ) and in the policresulen + cinchocaine group 3.4 (range 1-6, $\mathrm{SD}=1.35)$. Statistical analysis showed no significant difference $(p=0.1)$.

At the first evacuation, the mean values of pain intensity by patients assigned in the visual analog scale was 7.7, not statistically significant ( $p=0.67$ ) (Figure 4).

It was observed that the postoperative instructions were completely followed by $83.33 \%$ of patients in the control group, $93.33 \%$ in the placebo group and $86.66 \%$ of the individuals of the ointment group. Application of Fisher's exact test for nonparametric variables showed no statistical differences when comparing the frequencies between groups: $p=0.5$.

Finally, as for subjective analysis, $86.66 \%$ of placebo patients liked using the ointment, whereas in the policresulen + cinchocaine group the ratio was $66.66 \%$. Application of Fisher's exact test showed no statistical significance between groups ( $p=0.19)$.

\section{DISCUSSION}

Hemorrhoidectomy is the most effective treatment for hemorrhoids ${ }^{14}$, pain symptoms being its main obstacles 15. The most used technique is the open surgery, MilliganMorgan technique ${ }^{11}$, considered the "gold standard" for this type of procedure ${ }^{16}$.

The mean age of patients submitted to hemorrhoidectomy was 45.98 years, with no statistical difference between groups, making them comparable in regard to this variable. These data were, likewise, consistent with the literature ${ }^{14}$

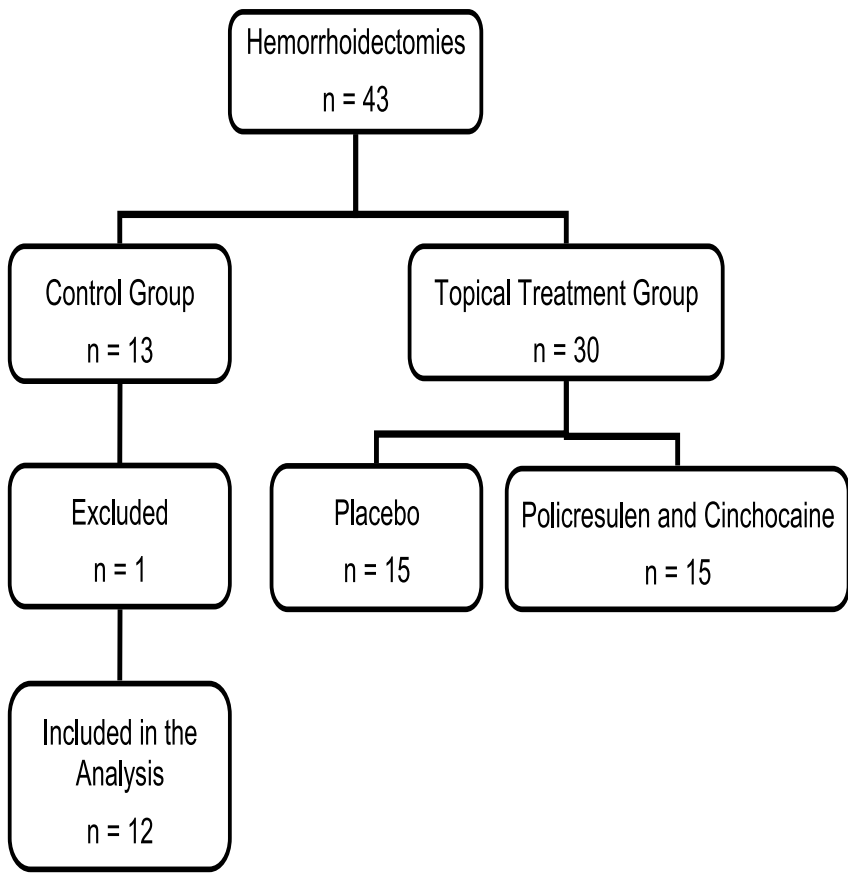

Figure 3 - Scheme showing the distribution of the subjects in the three study groups.

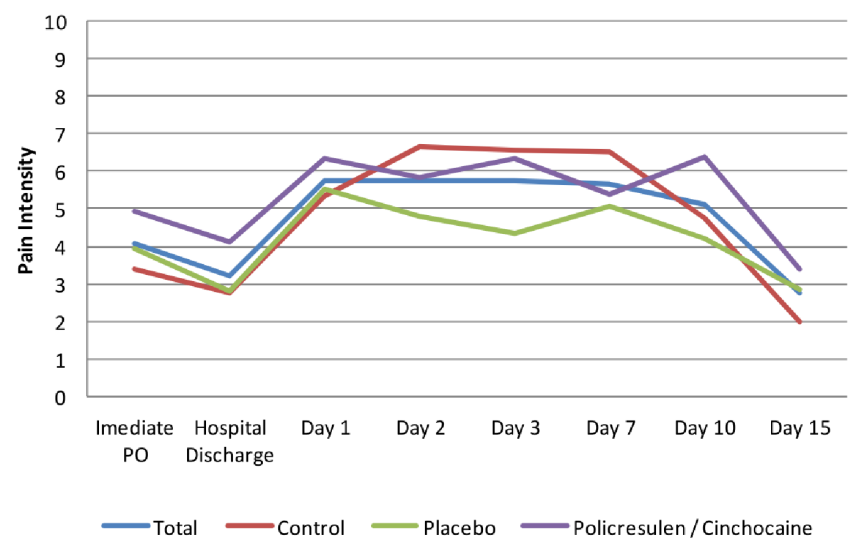

Figure 4 - Values of pain as postoperatively measured by the visual analogue scale (all periods). There was no significant difference between groups in all periods analyzed. 


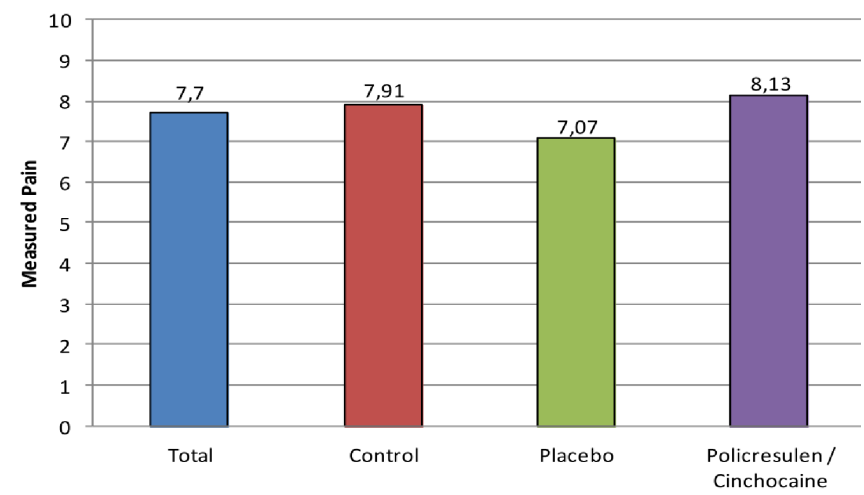

Figure 5 - $\quad$ Average value of measured pain on the analog scale of the respective groups at the time of first bowel movement. There was no statistical difference between groups $(p=0.67$ ).

Of all patients included, $37.2 \%$ were men and $62.8 \%$ women. There was statistical difference regarding the policresulen + cinchocaine group (men - 20\%; women - 80\%; $p=0.02$ ). The placebo group showed a trend towards statistical significance $(p=0.07)$. Demographic comparison between groups using the ointment showed no significant difference. The random aspect of this research did not allow control over patients, but the one recommended in the criteria for inclusion and exclusion criteria cited in the methods. There was no systematic randomization in this work, which probably did not distribute men and women more evenly between groups. The use of nonparametric tests was due to the population factor, associated with unknown, non-standardizable samples. Interestingly, in the literature there is a no significant trend in prevalence of men in studies involving patients undergoing hemorrhoidectomy ${ }^{17}$. In this study, we observed the opposite.

Despite the optimal statistical model for analysis of visual analogue scales is yet to be established ${ }^{18,19}$, the use of certain tests such as Student's t, ANOVA, MannWhitney and Kruskal-Wallis to detect differences in found measurements is widely applied in the literature ${ }^{20,21}$. Vacanti stated that when the data are not normally distributed or when they are on ordinal pattern measure, for example the anesthetic ASA scale and Visual Analogue Scale, nonparametric tests should be used. The Mann-Whitney test is the equivalent nonparametric test to the Student's t test. The Kruskal-Wallis test, on its turn, would be equivalent to the Mann-Whitney test for two or more groups ${ }^{22}$.

Regardless of the gender heterogeneity existing between the control, placebo and policresulen + cinchocaine groups, the use of the ointment containing or not active ingredients did not cause significant change in the natural history of postoperative pain symptoms of open Milligan-Morgan hemorrhoidectomy. The mean values of pain intensity assigned by the patients were not significantly different between groups in all periods, from the immediate to the 15th postoperative day. The use of the ointment containing or not policresulen and cinchocaine did not change the painful parameters compared with the control group. Thus, there was no influence of the use of any ointments in reducing pain after hemorrhoidectomy. This reflects the daily life of proctologists, fueling the controversy over the issue since the late ' $60 \mathrm{~s}$. To date, there is no consensus in the specialty regarding the use or not of ointments for pain reduction, and each expert has his own method of conducting patients ${ }^{9}$.

Pain symptoms were less intense in the immediate postoperative period. On arrival to the ward and at the time of hospital discharge, the patients were under the influence of intravenous medications and residual local anesthesia. After leaving the hospital, there was a slight increase in the level of pain on the visual analog scale due to the early use of oral medications. It is important to note that at least $83.33 \%$ of the patients followed the guidelines properly. This variation of pain intensity is due possibly to the greater analgesic potency of intravenous over oral medications.

It is known that the first evacuation is the most intense painful moment after hemorrhoidectomy ${ }^{15}$. The average assigned values between groups was 7.7 ( $p=$ $0.67)$, with no statistical significance between them. They were the largest values reported throughout the study. The first evacuation occurred between the second and third days, with no difference between groups $(p=0.1)$. Patients in group policresulen + cinchocaine evacuated on average a day later, with no statistical difference. One justification for this finding would be the prevalence of women in this group, for whom constipation and fear of pain when defecating tends to be more prevalent. We could not characterize whether there was active influence of the ointment in this finding.

The passage of fecal matter through the operated area associated with secondary sphincter hypertonia causes severe pain to the patient, regardless of care and applied postoperative approach ${ }^{23}$. This work demonstrated exactly what exists in the literature because the higher values assigned to pain were found during the first evacuation. Furthermore, there was no protective effect of the use of ointments in pain decrease in this difficult phase of the postoperative period.

The present study demonstrated that, after this peak of pain, coincident with the first evacuation, there was a sort of plateau in its intensity curve until about the tenth day after the date of the operation (Figure 3). Thereafter, a decline was observed, with a reduction of the associated values in the first follow up (day 15). This observation is in agreement with the subjective experience of proctologists and, therefore, this study confirms the reality of the painful profile after hemorrhoidectomy.

The cause of pain after hemorrhoidectomies (mostly open ones) remains inconclusive. In thesis, it is considered multifactorial ${ }^{24}$. The main factors that justify is iatrogenic injury to the anal mucosa ${ }^{25}$, intense local 
inflammatory response, spasm of the internal sphincter and the passage of fecal matter ${ }^{26}$. The formation of linear, slow healing surgical wounds, similar to anal fissures, and the additional bacterial inflammatory stimulation on the operated area, can also cause pain ${ }^{27}$. In the present study, the protocol of postoperative guidelines with or without the use of ointment attempted to minimize many of these factors. However, no systemic or topical antibiotic therapy was used, a way to combat bacterial factor in the genesis of pain.

Studies on chemical sphincterotomy associated with hemorrhoidectomy using calcium blockers, nitrates and botulinum toxin channels are effective in reducing pain from the third and fourth days after surgery, even causing significant reduction in anal resting pressure already in the immediate postoperative period ${ }^{4}$. This approach also matches the time at which most patients eliminate fecal matter, the moment of greatest pain recorded on the visual analogue scale. It was not the aim of this study to evaluate the effect of the reduction of the internal sphincter muscle spasm. In the post- operative instructions, we did not use any ointment substances that act for this purpose. A future perspective of this study is to add a new group of patients with this type of medication.

Most of the patients were satisfied by using the ointment. Personal accounts coincided to mention the comfort and feeling of freshness associated with the application of the ointment in the perianal region, especially in the first group. In the group receiving policresulen and cinchocaine, some patients mentioned burning and anal and perianal itching just after applying the ointment, without, however, limiting the application as directed on the prescription at the time of hospital discharge, but restricting the degree of satisfaction. The literature reports several cases of allergic dermatitis, mainly associated cinchocaine ${ }^{28}$, usually of benign course and no correlation with allergies to other local anesthetics of their same group (amide), such as lidocaine and prilocaine. The acidity inherent to policresulen in contact with the bloody tissue may also be associated with anal burning and itching ${ }^{8}$. The placebo group received ointment containing petrolatum and lanolin, which have a barrier effect and may be associated with the feeling of anal comfort and freshness ${ }^{29}$. Like any work, this study has limitations. Initially, sampling has been limited. Maybe with twice the patients included the trends could be undeniably confirmed. The healing changes that occur throughout the organic aging are now known ${ }^{30}$. A larger sample would allow stratification of groups by age and gender, favoring more specific and meaningful statistical data. Additionally, letting the filling of the visual analogue scale by patients themselves may cause bias, since not everyone has the same level of understanding of the exhaustive guidance provided. Finally, one can never forget that pain is a subjective and highly variable symptom among individuals. There is no standardization that is accepted worldwide for its measurement.

The hemorroidal postoperative period also presents numerous situations based on traditional usages, on old routines employed in Coloproctology services and on personal experiences. There is a significant need to carry out further randomized, double-blinded controlled studies to obtain evidence which corroborates the conduct that will bring real benefits to patients, intensely affected by pain and postoperative discomfort.

We conclude that the use of ointments has not reduced the intensity of pain in patients undergoing hemorrhoidectomy. We believe that patient care, mutual trust, meticulous operative technique and the detailed guidelines after the operation are still the most important measures for a more comfortable and appropriate postoperative period.

\title{
R E S U M O
}

\begin{abstract}
Objetivo: avaliar a ação do policresuleno e cinchocaína tópicos no comportamento da dor no pós-operatório de hemorroidectomias abertas. Métodos: estudo prospectivo, duplo cego e controlado. O grupo controle recebeu as orientações usuais com medicações de uso oral. O grupo de tratamento tópico recebeu, adicionalmente, a aplicação de pomada e foi composto de dois subgrupos (policresuleno + cinchocaína; e placebo). A intensidade da dor foi registrada a partir da escala visual analógica. Resultados: foram operados 43 pacientes: grupo controle $(n=13$; um excluído), placebo $(n=15)$ e policresuleno + cinchocaína $(n=15)$. A média de idade foi 45,98 anos e 37,2\% foram homens. A média da intensidade da dor foi 4,09 (PO imediato), 3,22 (alta hospitalar), 5,73 (dia 1), 5,77 (dia 2), 5,74 (dia 3), 5,65 (dia 7), 5,11 (dia 10), 2,75 (dia 15) e 7,70 (primeira evacuação), sem diferença entre os grupos em todos os períodos estudados. Conclusão: este estudo não demonstrou redução da dor após hemorroidectomias como o uso do tratamento tópico.
\end{abstract}

Descritores: Hemorroidas. Hemorroidectomia. Dor pós-operatória. Analgesia.

\section{REFERENCES}

1. Riss S, Weiser FA, Schwameis K, Riss T, Mittlböck M, Steiner G, et al. The prevalence of hemorrhoids in adults. Int J Colorectal Dis. 2012;27(2):215-20.
2. Moreira JPT, Araújo SEA, Oliveira Jr O . Projeto Diretrizes Hemorróida: Diagnóstico. Associação Médica Brasileira e ConseIho Federal de Medicina. São Paulo; 2005. Available from: URL: http://www.projetodiretrizes.org.br/4_volume/14-Hemorroidadiagnostico.pdf. 
3. Chen JS, You JF. Current status of surgical treatment for hemorrhoids-systematic review and meta-analysis. Chang Gung Med J. 2010;33(5):488-500.

4. Ho YH, Seow-Choen F, Low JY, Tan M, Leong AP. Randomized controlled trial of trimebutine (anal sphincter relaxant) for pain after haemorrhoidectomy. Br J Surg. 1997;84(3):377-9.

5. Place R, Hyman N, Simmang C, Cataldo P, Church J, Cohen J, et al. Practice parameters for ambulatory anorectal surgery. Dis Colon Rectum. 2003:46(5):573-6.

6. Espinosa DJ. Revisión analítica de estudios multicéntricos con policresuleno en patología hemorroidal. Acta Gastroenterol Latinoam. 2000;30(3):177-86.

7. Arnold K, Abele I, Auel H. Multicentre clinical study of a novel preparation devoid of steroids in proctology. MMW Munch Med Woschenschr. 1982;124(suppl 1):26-31.

8. Lee AY. Allergic contact dermatitis from dibucaine in Proctosedyl ointment without cross-sensitivity. Contact Dermatitis. 1988;39(5):261.

9. Cruz GMG, Alvarenga IM, Constantino JRM, Andrade MMA, Gomes DMBM, Faria FF, et al. Como o coloproctologista brasileiro vê a doença hemorroidária: análise de dados colhidos de questionário dirigido aos especialistas filiados à Sociedade Brasileira de Coloproctologia. Rev bras coloproctol. 2009;29(2):174-91.

10. Banov L Jr, Knoepp LF Jr, Erdman LH, Alia RT. Management of hemorrhoidal disease. J S C Med Assoc. 1985;81(7):398-401.

11. Milligan ETC, Morgan CN, Jones LE, Lond MB, Officer R. Surgical anatomy of the anal canal, and the operative treatment of haemorrhoids. Lancet. 1937;13:1119-24.

12. Wolff BG, Fleshmann JW, Beck DE, Pemberton JH, Wexner SD. The ASCRS Textbook of Colon and Rectum Surgery. New York: Springer; 2007.

13. Hospital Universitário Cajuru. Manual para identificação e estratificação da dor. Curitiba: HUC; 2011.

14. Madoff RD, Fleshman JW; Clinical Practice Committee, American Gastroenterological Association. American Gastroenterological Association technical review on the diagnosis and treatment of hemorhoids. Gastroenterology. 2004;126(5):1463-73.

15. Ba-bai-ke-re MM, Huang HG, Re WN, Fan K, Chu H, Ai EH, et al. How we can improve patients' comfort after Milligan-Morgan open haemorrhoidectomy. World J Gastroenterol. 2011;17(11):1448-56.

16. Cheetham MJ, Phillips RK. Evidence-based practice in haemorrhoidectomy. Colorectal Dis. 2001;3(2):126-34.

17. Loder PB, Kamm MA, Nicholls RJ, Phillips RK. Haemorrhoids: pathology, pathophysiology and aetiology. $\mathrm{Br} J$ Surg. 1994;81(7):946-54.

18. Dexter F, Chestnut DH. Analysis of statistical tests to compare visual analog scale measurements among groups. Anesthesiology. 1995:82(4):896-902.
19. Scott J, Huskisson EC. Graphic representation of pain. Pain. 1976;2(2):175-84

20. Myles PS, Troedel S, Boquest M, Reeves M. The pain visual analog scale: is it linear or nonlinear? Anesth Analg. 1999;89(6):1517-20.

21. McCrum-Gardner $\mathrm{E}$. Which is the correct statistical test to use? $\mathrm{Br}$ J Oral Maxillofac Surg. 2008;46(1):38-41.

22. Vacanti CMD. Essential clinical anesthesia. London: Cambridge University; 2011.

23. Torres Neto JR, Menezes DC, Prudente ACL, Almeida JC, Menezes JGT. Avaliação da analgesia pós-operatória em pacientes submetidos à cirurgia orificial com anestesia local associada ou não à morfina. Rev bras colo-proctol. 2007;27(1): 37-41.

24. Cesar MAP, Klug WA, Bassi DG, Paula PR, Cesar RP, Ortiz JR, et al. Efeito da nifedipina gel $0,2 \%$ nas pressões de canal anal e na dor pós-operatória: estudo após hemorroidectomia pela técnica aberta. Rev bras colo-proctol. 2007;27(4):364-73.

25. Ganio E, Altomare DF, Gabrielli F, Milito G, Canuti S. Prospective randomized multicentre trial comparing stapled with open haemorrhoidectomy. Br J Surg. 2001;88(5):669-74.

26. Ratnasingham K, Uzzaman M, Andreani SM, Light D, Patel B. Meta-analysis of the use of glyceryl trinitrate ointment after haemorrhoidectomy as an analgesic and in promoting wound healing. Int J Surg. 2010;8(8):606-11.

27. de Miguel M, Oteiza F, Ciga MA, Ortiz H. Tratamiento quirúrgico de las hemorroides. Cir Esp. 2005;78 Suppl 3:15-23.

28. Urrutia I, Jáuregui I, Gamboa P, González G, Antépara I. Photocontact dermatitis from cinchocaine (dibucaine). Contact Dermatitis. 1998;39(3):139-40.

29. Büyükyavuz BI, Sava ${ }^{\circ}$ C, Duman L. Efficacy of lanolin and type I collagen in the treatment of childhood anal fissures: a prospective, randomized, controlled clinical trial. Surg Today. 2010;40(8):7526.

30. Zouboulis CC, Makrantonaki E. Clinical aspects and molecular diagnostics of skin aging. Clin Dermatol. 2011;29(1):3-14

Received on $12 / 12 / 2012$

Accepted for publication 11/02/2013

Conflict of interest: none.

Source of funding: none.

How to cite this article:

Froehner Júnior I, Kotze PG, Rocha JG, Miranda EF, Sartor MC, Martins $J F$, Rejaile VA, Steckert Filho A, Corrêa MF. Postoperative topical analgesia of hemorrhoidectomy with policresulen and cinchocaine: a prospective and controlled study. Rev Col Bras Cir. [periódico na Internet] 2014;41(2). Disponível em URL: http://www.scielo.br/rcbc

Mailing address:

llario Froehner Junior

E-mail: froehnerjr@yahoo.com.br 